\title{
Migration ambitions of academic youth
}

\section{KEYWORDS}

emigration, student migration aspirations, brain drain

\begin{abstract}
Kozielska Joanna, Migration ambitions of academic youth. Culture - Society - Education no. 1(17) 2020, Poznań 2020, pp. 319-338, Adam Mickiewicz University Press. ISSN 2300-0422. DOI 10.14746/kse.2020.17.13.2

The purpose of this article is to identify student migration plans. The presented data are included in the optics of comparing the migration aspirations of medical students and pedagogy $(N=289)$. The research sample of the entire project in quantitative analysis numbered 604 people, and it was students of Poznan universities: Adam Mickiewicz University; Poznan University of Technology; Medical University; Economic University; University of Arts in Poznań. External migrations of "white staff" are an important topic, for example, in public debates due to the wide context of consequences that may occur in an abandoned country, which is why this group was chosen as a reference group in relation to the group constituted by pedagogy students.
\end{abstract}

\section{Youth in the European Union}

Young Europeans make up $1 / 4$ of the European Union countries population (Dybowska, 2018: 175), and their position on the job market is determined by the hiring policy of the European Union. The position of the young Poles on the labour market depends on the hiring policy in Poland, which in connection with Polish accession is related to the employment policy of the European Union. As in Europe, also in Poland for many years no problems specific for young people

\footnotetext{
* ORCID https://orcid.org/0000-0002-2319-9644.
} 
correlating with their entry and participation in the labour market were noticed including this category in people of working age. The most important documents for shaping the European labor market (the White Book 1994 and the Lisbon Strategy 2000) requested the Member States of the European Union to promote an active attitude among young people and include this group in the mainstream of related policy areas, mainly national employment policies, but - despite the high (then) unemployment among young people and treating employment as a priority for stimulating development - no threshold values for employment rates for young people were defined in the Lisbon Strategy. These issues have been clarified in the European Youth Pact ${ }^{2}$ (2005) and the Youth Guarantee document (2013), which focus on measures to provide young people with good-quality work, internships, apprenticeships and systematic education that takes into account their opportunities, favouring their entrepreneurial development, volunteering, integrating youth issues into broader policy areas. (Grotowska-Leder, 2018: 36). One of the main goals of the European Union programs aimed at youth is undoubtedly the promotion of broadly understood investments in human development and supporting them in their pursuit of acquiring knowledge and increasing the quality of educational services in the Member States. EU documents dealing with the subject of youth draw attention to the importance of human education throughout life - seeing it as opportunities for individual, social and cultural development, improvement of living standards and the creation of a Europe without borders and barriers through education (Dybowska, 2018). Young people perceive membership in the European Union as (mostly) positive, assigning it a control function, open borders, higher

\footnotetext{
1 The European Commission has proposed that ministers responsible for youth policy ensure that youth concerns are mainstreamed into other policies, both at national level and in the application of European policies. This applies to, inter alia, employment, education, formal and informal teaching methods, social integration, combating racism and xenophobia, immigration, consumer issues, health and disease risk prevention, equal opportunities for women and men. The goals set are: increase youth participation in society by introducing and supporting measures to encourage young people's active citizenship, improve youth access to information, develop, facilitate, support and reward voluntary activities. Numerous steps have been taken to better understand and know the problems of youth, as well as to ensure adequate quality, comparability and reliability of knowledge in the field of youth (Dybowska, 2018).

2 This document was included as an integral element in the Lisbon Strategy task package - the priority is employee mobility. The basic condition for the free movement of workers is the recognition of diplomas and professional qualifications in EU countries. This is to be achieved by the Europass system, which includes, among others, Europass-Supplement to the university diploma, i.e. a standardized document with detailed information on the program of studies; Europass CV, i.e. the model of the European curriculum vitae and Europass-Mobility, where the skills and knowledge acquired outside the home university are confirmed, especially during foreign scholarships, internships, apprenticeships and trainings (Dybowska, 2018).
} 
political and economic standards (the EU as a specific point of reference), supporting culture, investment activities in human capital (internships, training) and community strength against threats. The concerns of young people, on the other hand, focus on the issue of immigration from Ukraine, Poland's secondary position in EU structures, the fall of values and the unprofitability of EU membership (Niemczycki, 2018: 48-50). It is a fundamentally unchanging tendency, having its genesis already in the period around the accession (cf. Cybal-Michalska, 2001: 96).

Global experience shows that the vast majority of all migrations - starting with those conditioned by armed conflicts or climate change, and ending with the most common economic migrations - mainly concern people in the so-called mobile working age, i.e. young people, and the migrations themselves have been and are an element of social change (Kaczmarczyk, 2018: 53). Permanent, dynamic volatility, multi-context nature of transformations in the labour market, including the emerging real possibility of pursuing careers beyond the borders of the home country, and finally transnationalisation or de-territorialisation of work are just some (in fact already standard) features of behaviour on the labour market. All these changes became more intense and intertwined even more smoothly with people's biographies after Poland joined the European Union in 2004 (Grabowska-Lusińska, Okólski, 2009; Engbersen, 2012).

The guarantee of the availability of European labour markets was a very important element of Polish foreign policy during the negotiation of the conditions under which Poland was to become a member of the European Union. ${ }^{3}$ At the time of Polish accession, Poles as citizens of United Europe gained the right to work legally in other Member States. This opportunity was used mainly by Polish youth "third generation immigrants"4 - tempted by better wages and future prospects. Due to the fact that the possibility of realising one's professional biography in a transnational dimension is currently one of the "options to choose" in planning and implementing educational and professional choices, or more broadly in the

${ }^{3}$ It took place on May 1, 2014. Currently, according to polls, the support of young people for the European Union is still unquestionably high - it reaches over 80.00\% (Niemczycki, 2018: 45). A CBOS poll from 2017 shows that the group of young people most often supports the adoption of the Euro in Poland.

4 The post-accession phenomenon of emigration, including economic emigration, was called the "third generation emigration" due to the large number of emigrants and some hitherto unprecedented features of emigration. It is a typical economic emigration - following the example of Great Britain - it can be noticed that one-third of the men and two-fifths of women who arrived there before accession (eg in the post-war period) remained professionally inactive. On the other hand, "post-accession" emigrants in the vast majority of cases were people who were professionally active in England (95\% men, 80\% women) (Fihel, Piętka, 2007). 
education-labour market transition process, it was decided to devote a fragment of this study to characterize the EU law on labour mobility and show the basic features of the economic migration of (young) Poles. Young people build their careers in a transnational dimension. "Currently, leaving the country does not mean fleeing, but taking the opportunity to fulfill the right aspirations. Returns are not a failure, but the implementation of one's own life plans" (Bera, 2008: 84-85).

\section{Free movement of workers as an example of the uniformity of labour markets}

The bi-sectoral nature of the labour market (also in EU structures), expressed in a significant diversification of the Member States and the nature of work on national markets (highly exposed, well-paid positions requiring specialist education vs. jobs not requiring specialist qualifications), is conducive to migration. In the privileged segment, a small number of people find employment, while the peripheral segment, in turn, does not enjoy the interest of the native population of a given country. It is this sector that attracts emigrants from "peripheral" countries, because although wages do not constitute an incentive for citizens of developed countries, they are attractive to emigrants coming to them. The employment policy in the European Union is an important concept in relation to the discussed issues. Its indications and the opening of borders in the EU zone have become an important reason for making migration decisions.

The European Union is an economic and political union of 27 democratic European countries 5 , which is the result of many years of political, economic and social integration. Its aim is cooperation between states for peace and prosperity; it deals with a wide range of issues of direct relevance to the daily life of its citizens. Two basic functions of employment policy can be distinguished: social, determined by the current and future conditions of social development; and economic, related to economic development, other tasks include: reducing unemployment, eradicating poverty, filling the employment gap, influencing decisions on the choice between unemployment and inflation, and reorienting labour market institutions (Gogolewska, 2006: 403-404). All these activities are of interest to the employment policies of individual countries and the European Union in general. Employment policy is considered to be a component of social policy, which is clear from the definition of the latter, among others. The most important issues

\footnotetext{
${ }^{5}$ 20.02.2020 - Great Britain left the European Union.
} 
determining the subject scope of the Community social policy include the management of the employment strategy in the EU, the aim of which is primarily to ensure a high level of employment and to support the mobility of the workforce; protection of workers' safety and health; ensuring appropriate working conditions; informing and communicating with employees; integrating people excluded from the labour market, especially those unemployed for a long period; ensuring equality between women and men in terms of opportunities in the labour market and treatment in the workplace (Anioł, 2003: 7).

The European Employment Strategy (EES) is designed to guide and coordinate the employment policy guidelines that Member States are joining at European Union level. The premises of the common EES were adopted by the Extraordinary European Council at the 1997 EU summit in Luxembourg. Since then, it has played a central role in coordinating the employment policy of the European Union. It is an important tool for achieving the Lisbon Strategy goal of creating more and better jobs. It is also an element of the social dialogue of the European Community. At the same time, its philosophy is based on the belief that a higher level of employment and greater flexibility of labour markets can be achieved without sacrificing the foundations of solidarity and social rights on which the societies of the European Union are based. The objectives of the European Employment Strategy relate in particular to the creation of a skilled, trained and adaptable workforce and labour markets that are sensitive to changes in the economy. ${ }^{6}$ Instead of focusing on passive financial support for unemployed people, the main emphasis is on the employability (i.e. the ability of people to find employment) of job-seekers, entrepreneurship, constant adjustment of the labour market to economic and technological changes and equal opportunities for women, men and people with disabilities. ${ }^{7}$ The European Union sets out ten priorities, the achievement of which is crucial for the successful implementation of the EES. These priorities are: active preventive measures for the unemployed and the inactive; stimulating entrepreneurship and supporting the creation of new jobs; adaptation of companies and employees to changes, which is tantamount to an increase in the flexibility of the labour market; increasing and improving investment in human capital and developing a lifelong learning strategy; increasing labour supply and promoting economic activity in old age; equality between women and men; disseminating the idea of integration and combating discrimination against disabled people in the labour market; increasing the attractiveness of work through financial

\footnotetext{
${ }^{6}$ European Commission, European Employment Strategy. More and better jobs for all, Brussels 2006, http://www.eurofound.europa.eu/publications/htmlfiles/ef0850.htm.

${ }^{7}$ European Commission, European employment and social Policy; a Policy for people, Brussels http://ec.europa.eu/publications/booklets/move/24/txt_en.pdf.
} 
incentives; transformation of undeclared work into official employment; promoting professional attitude and geographical mobility and other activities aimed at levelling regional disproportions (Wiśniewski, 2005: 121-122). The European Commission bases its Employment Guidelines on four pillars which are supplemented and expanded over time. These pillars are: employability, entrepreneurship, adaptability and equal opportunities. The main activities of the European Union are based on these principles. ${ }^{8}$ First pillar: employability. As part of this pillar, the Member States of the European Union combat youth unemployment and long-term unemployment. The aim is to enable all young job-seekers to have a a fresh start before the end of the six months they have been unemployed, and all adults - before the end of the year. This new start may be education, training, apprenticeships, getting a target job, etc. Pillar 1 measures also include a gradual shift from passive (benefits and other forms of financial support) to active (courses, training, etc.) methods of combating unemployment and stimulating cooperation of social partners to create better opportunities for lifelong learning, vocational training, apprenticeships, etc. Second pillar: entrepreneurship. It comes from the understanding that jobs are created by entrepreneurs and that creating more and better jobs requires a favourable climate for business development. Third pillar: adaptability. It focuses on the adaptation skills of both employees and employers to changes in technology and the labour market, on restructuring and creating new products and services, changes in work organization, working methods and types of employment contracts, as well as readiness to organise and participation in training. This pillar aims to achieve a new level of balance between the business's need to make the employment relationship more flexible and the need for safety on the part of employees. Fourth pillar: equal opportunities. In turn, this pillar aims to support the changes taking place in European societies towards the full respect of the principle of gender equality in work. These changes should result in an increase in the professional activity of women. It is also about better balancing their share in employment in individual sectors of the economy. Important directions of activities under the fourth pillar include the development of services providing care for children and the elderly, as well as all programs facilitating women's return to professional activity after a longer break (e.g. caused by maternity leave). Another aim of the actions under the fourth pillar is also to facilitate the employment of people with disabilities. ${ }^{9}$

\footnotetext{
${ }^{8}$ European Commission, Ten years of European Employment Strategy, Brussels 2007http:// bookshop.europa.eu/eubookshop/download.action?fileName=KE7807329PLC_001.pdf\&eubphfUid=570201\&catalogNbr=KE-78-07-329-EN-C.

${ }^{9}$ Representation of the European Commission in Poland, ABC of the European Union. Employment policy in the European Union, Warszawa 2004.
} 


\section{International migrations - theoretical indications}

Migration of people is not a new phenomenon, related to the specificity of our era, although in the era of globalization changes it is much more visible, if only due to the ubiquitous mass media. Experts define migration or migration movement as "the entirety of shifts leading to the change of residence of people who move from the place of residence or place of departure to the place of destination or place of arrival" (Bera, 2008: 77). Migration is defined as a permanent or relatively permanent change of residence - horizontal migration - taking place in geographical space. It is worth noting that this change is also accompanied by a change in the "social position" (Kawczyńska-Butrym, 2009: 11). Which means that the migrant "is forced (chooses) to part with family members, friends, on a larger scale - members of an ethnic group, nation, which in a broader sense is associated with a change in the surrounding social relations (a change in the institutional environment)" (Kaczmarczyk, 2005: 8). This phenomenon may condition the change of position in the social structure - promotion or degradation, which in turn is referred to as vertical mobility - vertical migration. Horizontal migration may refer to movement within the country or the world. The first option is called internal migration, the latter - external migration. It is worth noting the fact that there are many types of migratory movements. (Górny, Kaczmarczyk, 2003; Maryński, 1984; Slany, 1995, Okólski, 2004; Jończy et al., 2003). Kawczyńska-Butrym proposed an extensive analysis and typologies, giving the type of external migrations and the categorization criterion. The author lists several criteria for the division of the phenomenon in question, dividing them into the criterion of the reason for the migration decision and the purpose of departure (e.g. economic/ economic/work migration, for the purpose of family reunification, non-economic, voluntary, forced, patriotic, political, religious, improvement of the quality of life), experiences, return) other; the criterion of the duration of migration (seasonal, permanent, settlement, periodic, long-term, short-term, definitive, shuttle, contract, circulation, transmigration) and the legality criterion (legal, illegal) (Kłos, 2006: 2; Bera, 2008: 77-78; Okólski, 2009: 11; Baj, 2007: 101; Okólski, 2002: 3; Iglicka, 2002: 17-23). An important migration phenomenon is fluid migration ${ }^{10}$ with transmigration, which R. Jończy (2007) calls suspended migration, de-dramatized migration (Kubitsky, 2012). with the free movement of labour, it is characterized by massiveness, "super-diversity", "plasticity" and "permanent temporal-

${ }^{10}$ Named so by M. Okólski in reference to contemporary European processes - liquid modernity described by Z. Bauman. 
ity", which are becoming objective features, more and more universal marks of migration in the globalized world of human wandering (Okólski, 2009: 7-14). We can distinguish several theories indicating the causes of migration, they include, for example: economic, social and geographical theories (Janicki, 2007: 285-304). Due to the multitude of theoretical references to the phenomenon of migration, the next part of the paper will present theories of migration, which are important in relation to post-accession "liquid migrations", including those made "on trial" (reconnaissance).

Economic theories assume that economic factors have the greatest influence on the decision to migrate. According to the Classical Theory - the macroeconomic plane of the decision to migrate, man is Homo oeconomicus (Bittner, 2006) - which rationalises its actions and moves in search of better living conditions (Janicki, 2007: 287). Non-economic costs of migration, such as psychological costs, related to longing as a result of separation, are not included in economic theories. These theories link migration mainly to the labour market, labour demand and supply, financial conditions, and the degree of unemployment (Szaban, 2009: 8-12; Janicki, 2007: 287). Neoclassical Theory of Foreign Migration, "is the result of bringing the classical theory closer to reality (...) migration is the result of differences in the size of labour demand and supply in different areas, which results in the differentiation of wages, and migration is a process that compensates for these differences" (Janicki, 2007: 288). The discussed theory assumes that making a decision is the result of individual, individual calculations of losses and gains, which are the potential result of displacement. "The goal of emigration is to achieve maximum work productivity, therefore profit is understood as the difference in productivity in the place of the new and previous stay" (Janicki, 2007: 288). When estimating profits and calculating them before departure, one should take into account the probability of receiving (or not) a financially satisfactory (due to the nature of the concept) unit of work. In this concept, in contrast to the previously mentioned, psychological costs are added to the co-calculative pool (migration shock, longing, family separation (Janicki, 2007: 288). The New Economic Theory of Migration was developed on the basis of the assumptions of the neoclassical theory, hence it is often treated as its modification (Szaban, 2009). They are, however, differentiated by the fact that, in the discussed case, a possible decision to leave is made by family members, and thus the micro concept of calculating potential profits and losses is rejected in favour of the calculation resulting from considerations of household members. (Szaban, 2009; Janicki, 2007). The theory of the dual labour market, contrary to the new economic theory, basically concerns only the receiving party - the country of emigration (considering this issue from the perspective 
of the sending country). Its assumption is a constant shortage of employees in countries with a high level of development, due to the existing sector, which for prestigious reasons, is not popular amongst native population (Janicki, 2007: 290). The World System theory assumes that migration is "a natural consequence of the development of capitalism" (Janicki, 2007: 291). In the light of the discussed theory, the reason for leaving the country (for economic reasons of course) is not the differences in the level of wages, but the "structure of connections of the world economy" (Janicki, 2007: 292; Szaban, 2009: 27).

The feature that differentiates sociological theories from economic theories is the fact that sociological theories generally focus on the motives of the decision to emigrate, often completely ignoring economic factors (Szaban, 2009) and so - the Theory of Migration Networks assumes that the most significant influence on making decisions about migration have interpersonal, personal, family, friendly or neighbourly relations between former or present (visiting the country of origin) migrants and future emigrants. For people considering to migrate, emigrants are the best source of information about the benefits and dangers of migration. In addition, it is also with family and friends that you seek support in the first days of your stay abroad. Therefore, migration is perceived as a network of events, feedback loops, information exchange network (Szaban, 2009). Institutional Theory is similar to the previously presented theory of migration networks, but it is "generated by institutional connections" (Janicki, 2007: 293). In order to meet the needs of migrants, provide travel facilities, facilitate departure and arrival to a given country, organize living in emigration and work - companies and organizations are created, both non-profit and commercial type, such institutions include companies that for a fee they deal with finding foreign employment for those planning to leave. International corporations and transnational employers posting employees to other countries also fit into this concept. According to this theory, subsequent groups of immigrants are not related to the causes of the migration of primary immigrants, therefore the migration process is institutionalized (Szaban, 2009: 19-22; Janicki, 2007: 293, cf. research e.g.: Sakson, 2001). This theory, similarly to the theory of migration networks, assumes "he existence of a chain of feedback events. At its beginning there is the first group of migrants, and each subsequent flow results - indirectly - from the previous one, which increased the demand for services provided by companies supporting migrants" (Janicki, 2007: 293). The Cumulative Causality Theory also assumes that "subsequent waves of migration result directly from the previous ones" (Janicki, 2007: 294; Szaban, 2009: 19-22). Here, however, the most important role is played by non-individual social networks. It concerns, however, secondary, repeated emigration, seeing as their 
reason the desire to prevent a further reduction in the standard of living, which in the face of migratory earnings has improved significantly. Intermediate Opportunities Theory assumes that, contrary to popular belief, the size of migration and distance are not related to each other. The cause of migration is the existence of the so-called "Intermediate opportunities", that is, alternative destinations that compete with each other in attracting migrants. The more such opportunities there are between the two analysed places, the smaller the flow of people between them will be" (Janicki, 2007: 295). Proponents of the theory take as evidence of the existence of indirect opportunities the mere fact of "migration between the place of origin and places located between it and the studied destination" (Szaban, 2009: 20). The Indirect Obstacles Theory, also known as the Evertt Lee's Pushing and Pulling Factors Hypothesis (Szaban, 2009: 21), is to some extent a negative, the opposite of the above-mentioned theory of indirect opportunities. The author of the theory distinguishes four dominant factors influencing the decision to leave - migration. The first are related to the place of origin, the second are related to the destination, the next are "indirect obstacles" as the last ones, while the author lists personal factors. It is worth emphasizing that the first two groups of determinants contain an attractive, repulsive or neutral charge. W. Janicki (2007) quotes after Lee (1966) that "a simple calculation of the factors for and against does not immediately decide about the existence of the phenomenon of migration - there must be some stimulus that will overcome the smaller or greater inertia existing in every human being"11 (Janicki, 2007: 296; Szaban, 2009). It is impossible not to mention at this point the new theory proposed by Harald Bauder in 2006, presented by Kaczmarczyk, Tyrowicz $\left(2008^{12}\right)$, the author disorganises the above-mentioned proposals, claiming that it is not the labour market that is the determinant of migration, but that migration is the factor of changes in modern labour market. The author points out that typically immigrant employment sectors exist not because there is migration, but because people are willing to do so (Kaczmarczyk, Tyrowicz, 2008). Geographical theories (the theory of gravity, the hypothesis of the transition of spatial mobility), included in the typology of W. Janicki, are not the area of interest of this subsection, considering the fact that in the era of post-accession migrations (the policy of cheap flying, open skies) they are somewhat outdated. They assume that most migrants cover only short distances, each flow generates a similar return flow, and women are more prone to migration than men (Szaban, 2009). The theoretical framework concerning the educational and professional choices of young people,

${ }^{11}$ Inertia - it is a kind of attachment, a kind of brake, it is a measure of attachment to the place of residence (Janicki, 2007: 296). therefore, there must be an incentive to overcome it (Szaban, 2009: 21).

${ }_{12}$ Available at http://www.migracje.uw.edu.pl/publ/781/. 
which is the subject of this paper, means that the focus is only on those theoretical conceptualizations that translate into real processes. One of them, therefore, is the above-mentioned theory of economic indirect obstacles (push-pull) and elements of sociological concepts that assume the existence of a migration support network.

\section{Migration aspirations of academic youth}

Data from the Central Statistical Office show that after a noticeable decrease in the number of Poles temporarily staying abroad in 2008-2010, 2014 was another year of increasing the immigration resource of Poles in other countries - the office estimates that at the end of 2014, around 2,320 thousand inhabitants of our country, by 124 thousand (5.6\%) more than in 2013. The number of Polish residents temporarily staying abroad continues to grow - at the end of 2017, it amounted to approximately 2.54 million people. Among the EU countries, the largest number of people resided in Great Britain (685 thousand), Germany (614 thousand), Ireland (113 thousand), the Netherlands (109 thousand) and Italy (96 thousand). The most numerous age group among migrants staying abroad for more than three months are very young people (the group in the 25-29 age group; almost 383 thousand, of which $54.00 \%$ - 207 thousand - were women). The second largest group were people aged 30-34 years, followed by the age groups 35-39 (majority of men) and 20-24 (majority of women). In terms of the level of education, $40.50 \%$ of emigrants have secondary education, and every fifth vocational education $(24.00 \%)$, and $22.80 \%$ - higher (migrant women are better educated than men). The data of the Central Statistical Office indicate that $38.70 \%$ of people with higher education are people who completed social sciences, law, and most often economics. A greater percentage than it results from the structure of the education of the Polish population was recorded among emigrants who graduated from humanities and language sciences, biological sciences and computer science. The conclusion is that the decision to emigrate is facilitated by a good command of foreign languages (foreign philology graduates), the need for a given group of professions abroad (e.g. IT graduates), as well as difficulties in finding a job compatible with education on the Polish labour market (Szyszka, 2016) P. Kaczmarczyk emphasizes that the structure of migrants usually reflects the population structure of their country of origin. However, taking into account the fact that the greatest tendency to mobility concerns people aged 18 to 35 and at the same time, how much the level of education of the younger part of the Polish population has improved since 1989, it should not come as a surprise that the share of migrants with higher education 
is increasing (and is higher than those in the country). In addition, migration of people with higher education does not seem to be a brain drain, but rather a depreciation of qualifications, brain waste (not using qualifications due to working below qualifications or taking up employment without qualifications), which is not only a migratory feature. We are dealing here with the phenomenon of "double depreciation of qualifications" (not only at the time of, but also before migration) (Kozielska, 2014: 164). The drainage effect is not obvious in case of Poland. It turns out - even a simple analysis of data on unemployment according to the level of education - proves that people leaving Poland and having a university diploma often remained unemployed abroad and could not find satisfactory employment, or worked below their qualifications. This would mean that their departure abroad does not involve a high opportunity cost from the perspective of the sending country, which can be described as the brain overflow (Kaczmarczyk, 2018: 65).

The analyses of the Central Statistical Office show that people with basic vocational education ( $81 \%$ of them worked), with secondary vocational education (almost 78\% worked) and higher education (over 72\%) found jobs abroad most easily (Kaczmarczyk, 2006). The "brain drain" commonly signaled (especially in the media discourse, but also in scientific studies) was to clearly summarize the effects of the migration of educated Poles. Meanwhile, however, in the nineties of the last century, a new approach appeared, which significantly differentiated the previous paradigms. The so-called the new economics of brain drain is based on the belief that the possibility of going abroad may induce people to invest more in human capital (in anticipation of a higher rate of return on human capital abroad). Paradoxically, even an increased scale of migration of well-educated people can lead to an increase in the human capital resources in the country of origin of migrants, which in the literature is referred to as brain gain or beneficial brain drain (Stark, 2005; Beine, Docquier et al., 2008).

\section{Migration opportunities and threats in the opinions of students of pedagogy and medical university}

The topic of migration aspirations, taking into account, for example, the migration episode in the planning of educational and professional biographies appears to be important. Despite the fact that the migration boom is behind us, data from 2018 indicate that one in ten Poles considered emigration - i.e. 8.00\% of the entire adult population of Poland (almost 2.6 million people) - and more than half of them are "debutants" who plan to leave the country for the first time in order to take 
up employment. ${ }^{13}$ The youngest of the respondents - people between 18 and 24 years of age - are mainly interested in taking up immigrant employment. Among the respondents from the 25-34 age group, i.e. those who, as it can be assumed, have already had their first professional experience behind them and are currently probably stabilizing their situation on the labor market, interest in leaving the country is declared less frequently - they are looking for a job or intend to do it look for only every eighth of this group (13.00\%). ${ }^{14}$ Laboor migration is not a time wasted - a time of professional vacuum. On the contrary, it is often an intensified time of acquiring professional experience and competences, even when the work performed is not consistent with the professional education of the emigrant. It is also a time to accumulate financial capital (needed to open your own business, start your studies, etc.) and non-economic capital. This is a period that, if used rationally, can bear fruit in the future, and allows for the verification of the previously adopted educational path. (Kaczmarczyk, 2018: 68).

The surveyed students ${ }^{15}$ already have migration experiences on their biographical "accounts", and almost half of them consider leaving after graduation. Every fourth respondent has already experienced migration in person (economic and educational emigration; family emigration), and $93.00 \%$ of the respondents have people who are currently in emigration (economic, post-accession emigration) in their immediate vicinity (family, partner, friends).

Young respondents associate migration trips definitely with the economic aspect, few perceive them through the prism of new experiences, opportunities and challenges, stating that due to migration

(...) a person can get to know a new culture, admire other parts of the world, get to know the otherness of human characters, learn that you can live better, but also worse - thus appreciate what you have or desire something better. They can experience amazing adventures, feel free. This is how I see it, for many people a trip is associated with vacation and rest, as well as with looking for a job.

13 The declared length of emigration is a disturbing aspect. Almost every fourth respondent planning to leave does not plan to return to the country. What is equally important, more than $1 / 3$ of the respondents, regardless of the planned duration of the trip, plan to take with them families, which historically have constituted the largest migration barrier.

${ }^{14}$ https://www.cbos.pl/SPISKOM.POL/2016/K_175_16.PDF.

${ }^{15}$ AMU students majoring in pedagogy and students of the Medical University of Warsaw faculties: dietetics, pharmacy, nursing and medicine, $\mathrm{N}=289$. The research was conducted in 2018 (February-June) using the diagnostic survey method, using the proprietary questionnaire. 
Migration appears to students as an opportunity, less likely to perceive threats in it. Interestingly, more than half of the sample was unable to respond to the question. The in-depth analysis shows that the opportunities attributed to migration are, according to the respondents:

- the possibility of better earnings;

- work in an international environment;

- broadening horizons, e.g. meeting new people and their cultures;

- better living conditions and development of language competences.

Let it be exemplified here by the statement of one of the respondents:

(...) the trip broadens horizons, opens people and allows them to gain a lot of experience and promotes self-development. Going abroad also gives me experience that I think is welcome in my $\mathrm{CV}$.

Table 1. Migration - opportunity vs. threat

\begin{tabular}{|l|r|c|c|}
\hline \multicolumn{2}{|c|}{ Migration is } & $\begin{array}{c}\text { Adam Mickiewicz } \\
\text { University in Poznań }\end{array}$ & $\begin{array}{c}\text { K. Marcinkowski Medical } \\
\text { University in Poznań }\end{array}$ \\
\hline Opportunity & $108(37.50 \%)$ & 58 & 50 \\
\hline Threat & $5(1.70 \%)$ & 4 & 1 \\
\hline Hard to tell & $162(56.00 \%)$ & 72 & 90 \\
\hline Other & $14(4.80 \%)$ & 13 & 1 \\
\hline Total & $289(100 \%)$ & 147 & 142 \\
\hline
\end{tabular}

Source: own research

Among the threats the most frequently indicated were:

- a communication barrier that provokes other difficulties - long-term unemployment, conflict with the law or misunderstanding on the part of native residents and marginalization;

- loneliness, separation from the family;

- terrorist attacks.

Students positively assess the chances of finding a job in Poland, indicating that they have high and moderate chances for it (over $80.00 \%$ of indications), they are slightly less optimistic when assessing the chances of finding a job abroad, although nearly $90.00 \%$ of them points out that work done abroad by Poles is manual work and work below qualifications, and only a few "lucky" people work in accordance with their learned profession.

Students argue for the possibility of taking up a job not related to education as follows: 
I believe that people, even after graduation, may have problems with finding a job in their own profession, then there is a chance of earning money below their own qualifications. On the other hand, often working below qualifications ensures better earnings.

It is not a problem for me, seeing what chances are often obtained by taking up work in a profession that is often less paid and carries greater obligations.

If a person has been looking for a job for a long time and has no other choice, I believe that there is nothing wrong with working below qualifications, inconsistent with education, but while taking up such a job, the person should still look for a job in accordance with the profession.

I don't think you can judge it, it is an individual choice. Often, education is inconsistent with what we are really passionate about, so employment below qualifications may be more beneficial to the public. And who knows, maybe someone will discover what they're really keen on.

Young respondents in the vast majority of cases express understanding and positively assess people leaving the country, stating

I think it is a very bold decision and I do not judge such people badly, apparently they had no other choice or it was just their dream. There are sometimes answers with a slightly different colour, for example: „(...) I don't judge. Everyone has what they decided to do. However, I know from my own experience that this is a bold decision that costs a lot mentally and often physically. Regardless of whether you are a doctor or a cleaner, or a student. The picture that is created in our country about emigrants and how to live in another (richer) country is colourful, and all the difficult ones related to life in a foreign country are always ignored.

I think it is a tough decision to give up the life we used to do so far and to re-think and create a new life in another country. For sure they can be assessed as brave but sometimes they throw themselves into deep waters without thinking about the consequences, so some of them can be described somehow reckless.

They rate their chances of finding a job in Poland higher than abroad. 
Table 2. Assessment of the chances of finding a job in the profession

\begin{tabular}{|l|r|l|c|}
\hline \multicolumn{1}{|c|}{$\begin{array}{c}\text { How do you rate your chances } \\
\text { of finding employment in Poland }\end{array}$} & $\boldsymbol{\%}$ & $\begin{array}{c}\text { How do you rate your chances of } \\
\text { finding employment abroad }\end{array}$ & $\%$ \\
\hline Very good chance of employment & 7.19 & Very good chance of employment & 6.59 \\
\hline High chance of employment & 31.74 & High chance of employment & 25.15 \\
\hline Moderate chance of employment & 50.30 & Moderate chance of employment & 34.73 \\
\hline Small chance of employment & 8.98 & Small chance of employment & 23.95 \\
\hline Very small chance of employment & 1.80 & Very small chance of employment & 9.58 \\
\hline
\end{tabular}

Source: own research

Young respondents associate emigration work with well-paid work, challenging, physical, incompatible with education, difficult/strenuous, yet giving a sense of independence, and over $30.00 \%$ perceive it as attractive. Work in Poland appears to the respondents - which is extremely interesting - very similarly, although it is poorly paid, physical (similar to immigrant work), difficult / arduous, and inconsistent with education.

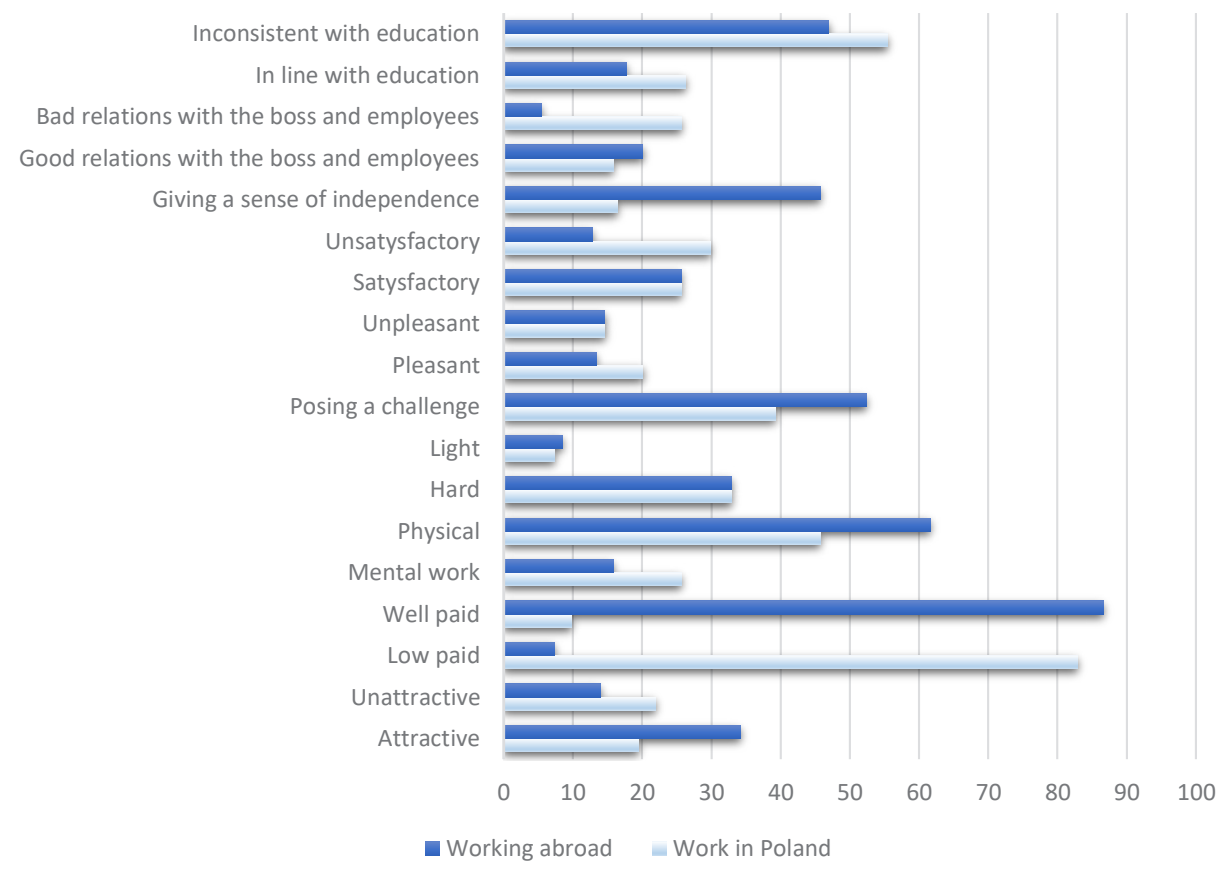

Fig. 1. Work-related associations - full posts - work in Poland, gradient - work abroad 


\section{Brain drain - pedagogues vs medical professionals}

$\mathrm{n}$ view of the term of the depreciation of qualifications or the brain drain (described in the first part of the text), it was questioning whether educated youth would undertake work below their qualifications abroad. Young educators in the vast majority of cases stated that yes (87.00\%), adepts of (approximately) medical faculties declared such intention less frequently $(57.00 \%$ - although more often than in the case of working below qualifications in Poland). The educators also more often indicated that they would take up jobs below their qualifications in the country of origin. Perhaps it results from the fact that the situation on the labour market is more favourable for medics and medical-related professions (for years they have been a deficit profession in virtually every region of the country), educators (excluding teachers of practical vocational training and vocational subjects) probably feel that their the situation is a bit less optimistic, hence consent to work below qualifications. It is worth referring to research by E. Ustymowicz and R. Bogusz (2014) on the migration aspirations of midwifery students, indicating that the respondents want to work and continue education in the learned profession. However, in the face of the realities of the Polish health care system, over 1/5 of female students declared their willingness to migrate for work, treating the trip as a serious alternative to continuing professional development in the country. Due to the deficit of tools for monitoring the emigration of Polish midwives and the lack of this type of scientific literature, it is difficult to present the real scale of the phenomenon. Existing data, including the presented results of own research, are

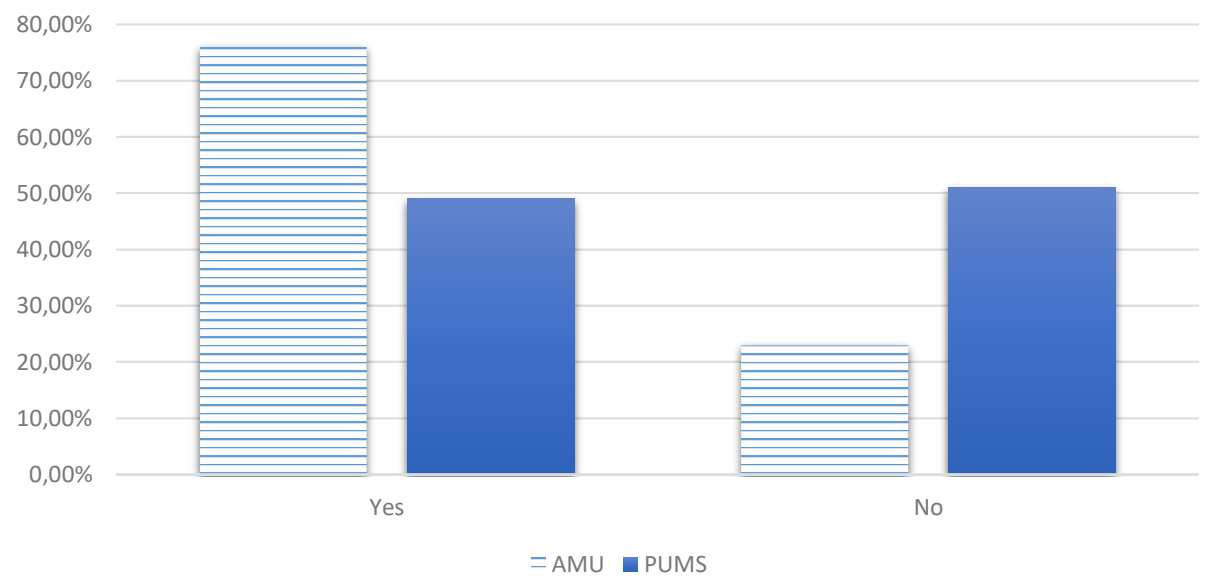

Fig. 2. Would you take a job below your qualification in the country? 
only indirect, however, they indicate a potential threat to the healthcare system. Moderate involvement in the preparation for the trip, as well as generally optimistic opinions of the surveyed students about the possibilities of professional development in the country, allow to assume that the actual scale of emigration in this group will be lower than declared (Ustymowicz, Bogusz, 2014).

The above results are confirmed in a study conducted among emigrants (2014), which indicates that the depreciation of qualifications has the hallmarks of a "double" because it takes place even before the decision to leave is made, often a factor pushing people out of the country (Kozielska, 2014).

\section{Conclusion}

Currently, we observe the phenomenon of consolidation of the so-called culture of migration, that is

(...) the consolidation of migration in the minds of participants in migration processes as an integral part of their lives. Even despite the awareness of the negative consequences, departures are tolerated or even desirable. What's more, (...) indicates a "gradual" migration - subsequent trips are the result of previous trips thanks to the obtained financial and socio-cultural resources, acquired knowledge and information, established contacts, learning the language, developing an attitude of resourcefulness. (Szyszka, 2016: 149)

Youth is an important segment of society and plays an important role in it as a link of "generational transfer" as well as "a driving force and a flywheel of social development and progress" (Zielińska, 2018: 9). In terms of research, however, it is an extremely interesting category of knowing about the contemporary society it entails various problems and tensions of the system. It is a measure of various changes and a barometer of social attitudes. The situation of young people, their way of perceiving the world, their aspirations and life goals are a measure of the changes that have already taken place and the distance still to be overcome (Szafraniec, 2011: 11). Therefore, it is important to be aware of the professional plans of this significant group, and foreign labour migration is one of the life strategies of young people under consideration - including people representing professions that are currently very desirable on the domestic market.

\section{Bibliography}

Anioł W. (2003), Polityka socjalna Unii Europejskiej, Warszawa.

Baj K. (2007), Stosunek Unii Europejskiej do nielegalnej migracji, Stosunki Międzynarodowe, no. 1-2. 
Beine M., Docquier F., Rapaport H. (2008), Brain Drain and human capital formation in developing countries: winners and losers, The Economic Journal 118 (528).

Bera R. (2008), Aksjologiczny sens pracy a poczucie jakości życia młodych emigrantów polskich, Lublin. Bera R. (2010), Wielka emigracja zarobkowa młodzieży, Lublin.

Cybal-Michalska A. (2001), Orientacje proeuropejskie młodzieży. Stan i perspektywy edukacyjne, Poznań.

Dybowska A. (2018), Europejskie programy dla młodzieży, http://orka.sejm.gov.pl/WydBAS.nsf/0/ 5F7ECC3808A82DD5C1257A30003C30F2/\$file/7_18.pdf.

Engbersen G. (2012), Migration transitions in an era of liquid migration, [in:] M. Okólski (ed.), European Immigrations. Trends, Structures and Policy Implications, Amsterdam.

Engbersen G., Snel E., de Boom J. (2009), Liquid migration from Central and Eastern Europe, [in:] R. Black et al. (ed.), Europe Moving West, Amsterdam.

Fihel A., Piętka E. (2007), Funkcjonowanie polskich migrantów na brytyjskim rynku pracy, Cefrm Working Papers, vol. 23/81.

Gogolewska J. (2006), Regulowanie rynku pracy, [in:] B. Winiarski (ed.), Polityka gospodarcza, Warszawa.

Górny A., Kaczmarczyk P. (2003), Uwarunkowania i mechanizmy migracji zarobkowych w świetle wybranych koncepcji teoretycznych, CMR Working Papers, no. 49, http://www.migracje.uw.edu. $\mathrm{pl} / \mathrm{publ} / 208 /$.

Grabowska-Lusińska I., Okólski M. (2009), Emigracja ostatnia?, Warszawa.

Grotowska-Leder J. (2018), Podejście dynamiczne w badaniach ludzi młodych z perspektywy rynku pracy - aspekty poznawcze i aplikacyjne, Rocznik Lubuski, vol. 44, pt. 1.

Iglicka K. (2002), Migracje powrotne Polaków. Powrót sukcesu czy rozczarowania? Warszawa.

Janicki W. ( 2007), Przegląd teorii migracji ludności, Annales UMCS, vol. LXII, pp. 285-304, http:// www.google.pl/url?sa=t\&rct=j\&q=przegl\%C4\%85d\%20teorii\%20migracji\%20ludno\%C5\%9Bci\%2C\%202007.\&source=web\&cd=3\&ved=0CFcQFjAC\&url=http\%3A\%2F\%2Fwww.umcs. lublin.pl\%2Fimages\%2Fmedia\%2Fpracownicy\%2F2788\%2FPrzeglad.teorii.migracji.ludnosci.-.tekst.pdf\&ei=fKHfT-rMBYTS-ga3mvHJCQ\&usg=AFQjCNFm11GPRF22CPdNKNH3SM$19 \mathrm{~K} \_J$ Eqg.

Jończy R. (2003), Migracje zarobkowe ludności autochtonicznej z województwa opolskiego. Studium ekonomicznych determinant $i$ konsekwencji, Opole.

Kaczmarczyk P. (2005), Migracje zarobkowe Polaków w dobie przemian, Warszawa.

Kaczmarczyk P. (2018), Młodzi $w$ dobie migracyjnej zmiany, http://mlodzi2018.pl/.

Kaczmarczyk P., Tyrowicz J. (2008), Migracje niepełne, Fundacja Inicjatyw Społeczno-Ekonomicznych, Biuletyn, no. 2.

Kawczyńska-Butrym Z. (2009), Migracje. Wybrane zagadnienia, Lublin.

Kłos B. (2006), Migracja zarobkowa Polaków do krajów Unii Europejskiej, Infos 2.

Kozielska J. (2014), Poakcesyjne migracje zarobkowe, Kontekst teoretyczno-empiryczny. Wsparcie społeczne, Poznań.

Kubitsky J. (2012), Psychologia migracji, Warszawa.

Maryański A. (1984), Migracje w świecie, Warszawa.

Niemczycki I. (2018), Europa dla Młodych, Młodzi 2018, http://mlodzi2018.pl/.

Okólski M. (2002), Migracje zagraniczne w perspektywie rozwoju demograficznego u progu przystąpienia Polski do Unii Europejskiej, [in:] Analiza zjawisk i procesów demograficznych w latach 1988-2001, Studia i Analizy GUS, Warszawa. 
Okólski M. (ed.) (2004), Mobilność przestrzenna z perspektywy koncepcji migracji niepełnej, [in:] Demografia zmiany społecznej, Warszawa.

Okólski, M. (2009), Polska jako aktor na europejskiej scenie migracyjnej, [in:] Współczesne migracje. Dylematy Europy i Polski, Warszawa.

Slany K. (1995), Między przymusem a wyborem. Kontynentalne i zamorskie emigracje z krajów Europy Srodkowo-Wschodniej (1939-1989), Kraków.

Stark O. (2005), The new economics of the brain drain, MPRA Paper 30939.

Szaban J. (2009), Migracja powrotna w województwie dolnoślaskim. Skala zjawiska, potencjał oraz pogłębiona charakterystyka powracających, http://www.cds.krakow.pl/zalaczniki/179/Raport\%20 KDS.pdf.

Szafraniec K. (2011), Młodzi 2011, https://nck.pl/badania/raporty/mlodzi-2011.

Szyszka M. (2016), Zagraniczna migracja zarobkowa jedną ze strategii życiowych młodego pokolenia, Roczniki Nauk Społecznych, vol. 8(44), no. 2.

Ustymowicz E., Bogusz R. (2014), Plany zawodowe i migracyjne studentów położnictwa, Medycyna Ogólna i Nauki o Zdrowiu, vol. 20, no. 1.

Wiśniewski Z. (2005), Europejska Strategia Zatrudnienia a aktywna polityka rynku pracy, [in:] A. Pocztowski (ed.), Praca i zarządzanie kapitałem ludzkim w perspektywie europejskiej, Kraków.

Zielińska M. (2018), Wstęp, Rocznik Lubuski, vol. 44, pt. 1. 